\title{
THE IMPACT OF ESG RATING ON CORPORATE BOND YIELDS
}

\author{
Balázs Kotró - Martin Márkus ${ }^{1}$
}

\begin{abstract}
This paper is to investigate whether markets assess corporate bonds riskier if their issuers have lower ESG (Environmental Social Governance) scores. For the study we used the corporate yield curves of Refinitiv further segmented by credit rating. The added risk of the ESG factor was measured in the time horizon of 2015 to 2020. It has turned out that in the USA in the group of the best debtor companies by Moody's investors expected companies with the lowest ESG scores to provide a 35 basis point higher risk premium compared to their counterparts with the highest ESG scores. This statement is also valid for the E, S and G-rating separately. In line with another trend, the riskier your credit rating category, the lower is the risk premium caused by the lack of responsible management.
\end{abstract}

JEL codes: G1, G11, G110, G120, Q5

Keywords: ESG investments, ESG risk, yield curve, yield spread

\section{INTRODUCTION}

In the study below we used the ESG factors (Environmental-Social-Governance), which have become the most generally applied to measure responsible, green, and sustainable investments (Amel-Zadeh-Serafeim, 2017). There is considerable literature on the study of the connection between return on equity and responsible investor behaviour. A paper by Gunnar et al. (2015) summarised the findings of approximately 2200 research studies on the connection between financial performance and ESG, while Orlitz et al. (2003) tried to reach substantiated conclusions summing up the results of 52 studies. Most studies have come to the conclusion that in their decisions for the capital markets investors do consider the extent a given issuer exerts a positive or negative impact on their closer or wider envi-

1 Balázs Kotró PhD student, Department of Investments and Corporate Finance, Corvinus University of Budapest. E-mail: balazsbence.kotro@uni-corvinus.hu.

Martin Márkus PhD student, Department of Investments and Corporate Finance, Corvinus University of Budapest.E-mail: martin.markus@uni-corvinus.hu. 
ronment, the society or the nature of their corporate governance practice and culture. According to the study of Bennani et al. (2018) as part of the Amundi Asset Management Research, compared to the market portfolio, 3.3\% extra profit could be achieved on the USA market from 2014 to 2017 by buying the best rated ESG shares and selling the worst rated ones, while in the same period $6.6 \%$ extra profit could be reached on the European capital markets applying the same strategy. Certain studies, however, have not found a clear and long-term connection between yields and responsible corporate management (Gillian-Starks, 2017). Fain (2020) has come to a mixed result regarding the connection between the financial performance and ESG score of a company. While a higher E, S and ESG rating had no significant impact on financial performance, a 10-point increase of the governance factor $(\mathrm{G})$ resulted in $0.3 \%$ improvement of the after-tax return on sales.

Banks, asset managers, pension funds and other investors use ESG factors both for risk management (Hoepner et al., 2020), and to utilise investment opportunities (van Duuren et al., 2015). In addition, country level ESG indicators may be applicable to evaluate welfare systems or to assess the general well-being of a country (Naffa-Dudás, 2020). The novelty and a point of interest regarding ESG based investments is that financial decisions are not based on financial indicators alone. If ESG related decisions play a part in investors' value judgement, it means the pricing of financial instruments must also be modified with non-financial factors in the future (Shrivastava et al., 2019).

Our research has proved the impact of ESG investments spread from stocks markets to bond markets exerting a different impact on the prices of corporate bonds of different maturity and belonging to different credit risk categories. That implies creditors consider their debtors' ESG rating to calculate profit expectations. They will deem companies riskier if their profile is less environment friendly if they fail to deal with social issues or if they mistreat their employees. If you can talk about risk premia linked to ESG factors on the bond market, it means that, in addition to shareholders, other stakeholders, such as creditors (bond holders) have become sensitive to added risk via their decisions although they are much less exposed to loss caused by a potential bankruptcy event, since in the course of bankruptcy proceedings creditors stand higher up in the order of payment than shareholders. The findings of our study have caused us to conclude that the impact of ESG based investments on pricing is strong enough to exert an influence on the value judgement of groups not directly involved in company profits (stakeholders).

The goal of the paper is to prove the existence of ESG based evaluation on the corporate bond markets using the yield curves built from bond prices. We expected the bonds issued by companies of lower ESG scores to be riskier, therefore their yield spread embodied in their yield curves being higher than that of companies 
having higher ESG scores. We investigated the overall phenomenon on the USA, European and Japanese markets, and we expected to find significant differences within the USA market narrowed down to different credit rating categories. Provided a difference of the yield spread of bonds issued by companies with lower and higher ESG rating can be observed within the same credit rating category, the question arises whether credit rating relying simply on financial indicators is sufficient to assess risk or whether you can talk about ESG risk in such cases.

\section{ESG AND ESG INVESTMENTS}

ESG is an acronym consisting of the abbreviation of the terms Environmental, Social and Governance. The internal and external activities of companies, management practices as well as their policies and regulations can all be analysed applying those three pillars, which may open up new vistas in risk management and the evaluation of capital market products.

The environmental variable measures the waste management, the emission of harmful substances or the ecological footprint of companies, while the social factor encompasses the connections of a given entity with those involved (suppliers, buyers, employees) and with society in general. It includes, among others, health, and labour safety regulations and how they are observed / made to be observed. Finally, the governance component is aimed to quantify corporate culture from gender diversity through the remuneration of top executives to the dataflow policy of companies (MSCI ESG Ratings, 2020). There is a growing number of fintech, and intelligence companies engaged in collecting, processing and publishing ESG metrics such as MSCI, Sustainalytics or Refinitiv. The Refinitiv ESG figures we used are updated weekly or ad hoc, if necessary, so both the sub-indicators and the summary ESG rating may change in time (Refinitiv, 2020).

Portfolio managers started to use responsible and sustainable investment strategies to assist making their financial decisions in the last decade. Earlier such strategies simply meant that an asset manager or a natural person investor banned from their portfolio industries like arms manufacturing, or sectors linked to tobacco or alcohol production. On the other hand, funds, ETFs and indexes also including ESG factors in their consideration have gained space and have become popular. Investors monitor and buy such baskets both to reach higher profit than the market portfolio and for risk management and because they intend to support long term sustainable goals with their investments (MSCI ESG 101, 2020). The above trend is supported by the USA SIF 2016 report saying every fifth dollar had been invested considering certain aspects of sustainability rather than financial issues only (USA SIF, 2016). ESG based investments have been seen ex- 
erting a significant impact mainly on the European and USA stock exchanges since 2013, which may be the result of ESG factors gaining weight in risk management or considerations of responsible mission-conscious investment opportunities gaining momentum. Interestingly enough, you cannot say that responsible investments have become a uniform trend in industrialised countries. Increased interest in ESG based investments you can find in North America and Europe has not started in Japan or Australia yet. The phenomenon can be explained, among others, by the conservatism and old-fashioned nature of Japanese corporate culture (Bennani et al.,2018).

\section{DATA MANAGEMENT AND DATA CLEANSING}

The companies in Refinitiv supported by corporate bond yield curves represent the universe of our research. Refinitiv build yield curves applying the cubic spline method and interpolate them to the relevant maturities. The curves built applying the method developed in 2001 by Waggoner, Anderson and Sleath provide more accurate forecasts with respect to flexibility, stability and smoothness than other methods of interpolation (Waggoner, 1997; Anderson, Sleath, 2001; Moore, 2017). 3100 observations were available. We filtered the set further as follows:

- Yield time series going back to at least 05.01.2015

- ESG time series going back to at least 05.01.2015

- Minimum 11 existing maturities

- Minimum 5 active bonds

- Maturity of the shortest bond is maximum 3 years

- There are bonds with over 10 years maturity

- Sum total of face value is minimum USD $1 \mathrm{M}$

- At least $80 \%$ of the time series is available

Yield curves of maturities from 1 to 15 years were examined. Long ends are typically extrapolated, so maturities over 15 years were not considered. Thus, the different points of the yield curves were the following: 1, 2, 3, 4, 5, 6, 7, 8, 9, 10, 12 and 15 years. If the last maturity was not available, we extrapolated (flat filled) the 12year figure. Any potentially missing data were filled in using observations from the previous day, so we received values for 1504 different days.

Applying the above filtering criteria, we received 135 corporate bond yield curves on the USA, 25 on the European and 29 on the Japanese markets. We paired with the issuers' credit rating and ESG variables as well as single E, S and G factors. Using single $E, S$ and $G$ variables we could examine smaller non-financial indicators 
separately, such as environmental or social impact. We examined the curves and the connections of the selected variables on a time scale of 5.5 years from January 2015 to July 2020 for all days available. The curves were arranged in order every day by their ESG, E, S and G scores, first on the given markets and then within the respective credit rating categories in the case of the USA companies. Next, following the arrangement by ESG, E, S and G, the top and bottom 10\% of the issuers of yield curves in the population were compared, i.e. we examined the difference of risk premium of the enterprises having the best and worst ESG scores. (When the partial universe proved to be too small, we used 5 observations instead of $10 \%$ ). It should be noted, since we were examining risk premia, the respective points of the risk-free yield curves of the relevant currencies were deducted from the different maturities of the yield curves. In case the maturity of a risk-free yield curve was not available, we used linear interpolation for the calculation.

We displayed the yield curves of the $10 \%$ best and $10 \%$ worst ESG rated companies on the given markets, as well as within the respective credit rating categories on the USA market using both cross-sectional and time series data. Please note the ESG, E, S and G-based arrangement of the companies of the population took place every day just as monitoring the changes in credit rating.

\section{FINDINGS}

\subsection{Differences of yield spread in daily breakdown}

Applying the process of data management described above, we have received the following results. Since we examined several yield curves in the different categories, their visualisation and the resulting conclusions were difficult to interpret. Therefore, we averaged the yield curves of the 10\% highest and 10\% lowest ESG rated companies by maturity weighted with the face values of the bonds of the different companies.

The yield curves were divided into three credit rating categories based on Moody's categorisation. The group „Prime 1 ” covered companies with the formal rating Aaa to A1, „Prime 2" included A2 and A3 categories while „Prime 3 ” covered Baa1, $\mathrm{Baa} 2$ and Baa3. Categories riskier than Baaz consisting of speculative debtors could not be included in the analysis, because less than $10 \%$ of the yield curves meeting the filtering criteria had that credit rating, so we did not have the sufficient number of data to draw confident conclusions. 


\section{Figure 1}

The distribution of the credit rating categories of companies meeting the filtering criteria from 5 January 2015 to 31 July 2020

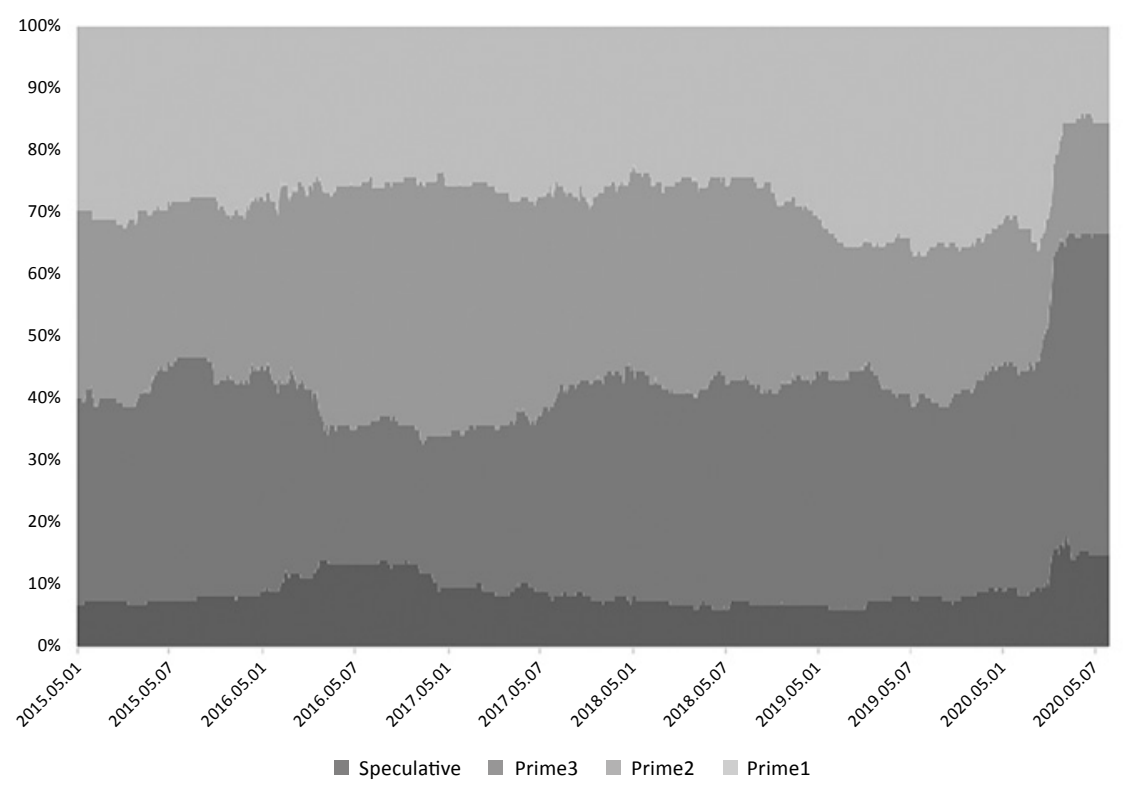

Although the credit rating of the companies examined was changing from day to day, it is clear the distribution of the groups Prime 1-3 was at around 30\%-30\%$30 \%$ within the universe filtered, while the speculative group remained stable at around $10 \%$. 


\section{Figure 2}

The highest and lowest $10 \%$ of the yield curves of bonds issued by the companies of the USA population arranged by their ESG, E, S and G scores within Moody's Aaa-A1 credit rating categories (Prime 1) as of 31 July 2020
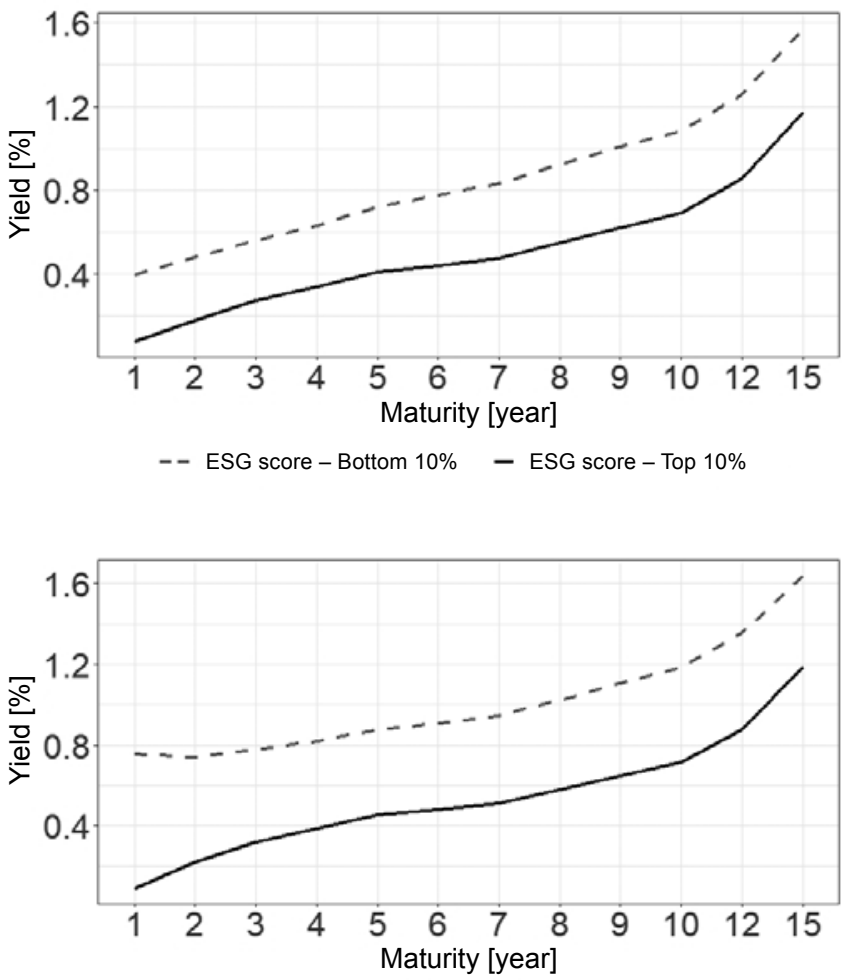

- - E score - Bottom 10\% - E score - Top 10\%

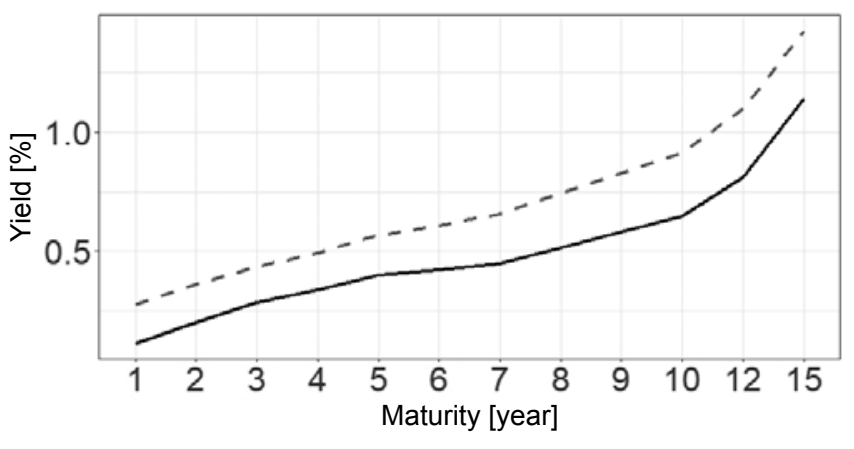

- - S score - Bottom $10 \%$ - S score - Top $10 \%$ 


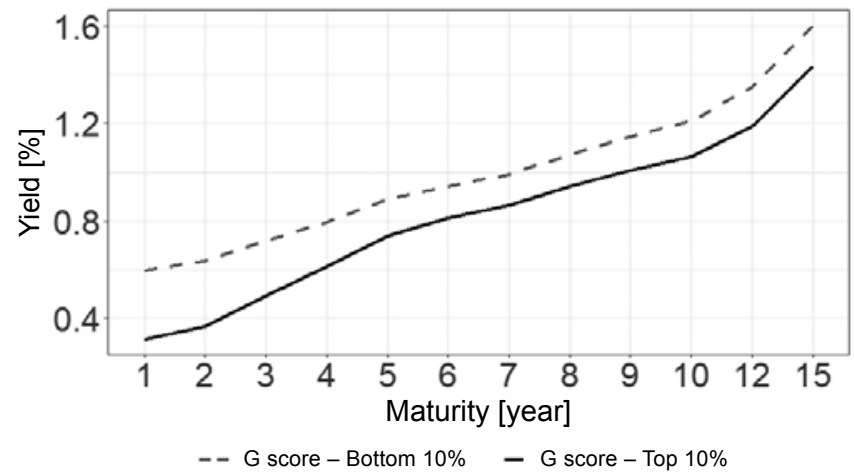

You can see in Figure 2 there was a significant difference regarding the expected rate of return on the bonds issued by the ESG based best performing and worst performing companies among the companies with the highest credit rating on the USA market. It means the market deemed debtors in the same credit rating category riskier if their ESG scores were worse. The phenomenon is the same based on the environmental (E), social (S) and governance (G) variables but the spread is different.

We also averaged the different maturities of the yield curves every day on the respective markets and in the respective credit rating categories. Table 1 includes the cross-sectional figures on the last day of the time period examined. As a result of strict filtering criteria, there was not a sufficient number of yield curves on the Japanese and European markets to draw confident conclusions regarding credit risk categorisation, so we could analyse the dimension of credit risk on the USA market only.

Table 1

The average difference of yield spread on the bonds issued by the companies of the universe filtered according to credit rating as well as the highest and lowest ESG, E, S and G-ratings as of 31 July $2020^{*}$

\begin{tabular}{lccccc}
\hline & USA Prime 1 & USA Prime 2 & USA Prime 3 & Europe & Japan \\
\hline ESG & 34.5 & 5.7 & -39.7 & -2.6 & -19 \\
\hline E & 47.2 & 7.1 & -32.8 & 1.5 & -21.2 \\
\hline S & 20.8 & -21.2 & -54.5 & -9.4 & -24.9 \\
\hline G & 17.6 & -46 & 26.9 & 0.8 & -1.2 \\
\hline
\end{tabular}

Note: ${ }^{\star}$ Average of yield spreads of companies with the lowest ESG rating - average of yield spreads of companies with the highest ESG rating (basispoints) 
Further conclusions can be drawn from Table 1. As of 31 July 2020, the better the credit rating of a debtor on the USA market is the more investors want to see how green the company in question is, how much it is socially responsible or how well it treats its direct and indirect partners or employees. You can see that investors may expect the best debtors to provide close on $0.5 \%$ yield spread. Investors having bought the bonds of debtors with the best credit rating but with a poor ESG expected 35 bp higher return on average compared to bonds in the same credit rating category but displaying a better ESG performance. It is evident that in Prime 1 the yield spread caused by the ESG rating is most impacted by the E (environmental) factor. This daily figure also allows to draw the conclusion that creditors are most sensitive to the environmental variable, they deem companies having a poor $\mathrm{E}$ rating the riskiest. The $\mathrm{G}$ (governance) rating is also important to them while they only respond to the $S$ (social) variable with 16.2 bp yield spread.

You can see that ESG based risk assessment has a diminishing role among companies having poorer debtor rating (groups Prime 2 and Prime 3). In Prime 3 creditors do not regard ESG as an added risk, on the contrary, they in fact penalise riskier debtors for investing into social and governance projects instead of striving to be good debtors. Thus, it is obvious that ESG-driven operation is the privilege of the best debtors. In other words, if a company belongs to the most solvent category, its investors really expect it to deal with social and environmental issues, so they expect ESG risk. As a result, the poorer credit rating category a company belongs to, the less investors are sensitive to responsible management. The importance of the E, S and $\mathrm{G}$ variables declines by approximately 50 bp by the different credit rating groups.

We could not draw unambiguous conclusions from cross sectional figures for Europe and Japan, so they were examined using time series analysis.

\subsection{Differences of yield spreads by time series}

The period examined is over 5 years; figures were analysed from 5 January 2015 to 31 July 2020 ( 1504 observations). We averaged the maturities of daily yield spreads, so the risk premia belonging to the same curve were concentrated into a single data point. While the portfolio is static, i.e. it includes the yield spreads of the bonds issued by the same companies from day to day, the ESG and credit rating of the different curves is dynamic, i.e. partial portfolios were set up every day subject to the ESG rating and credit rating of a company on that day (as ratings can shift from day to day). 


\section{Figure 3}

The weighted average of the yield curves of bonds issued by the companies of the USA population, the lowest and highest 10\% arranged by their ESG, E, S and G scores within Moody's credit risk category Aaa-A1 (Prime 1), from 5 January 2015 to 31 July 2020
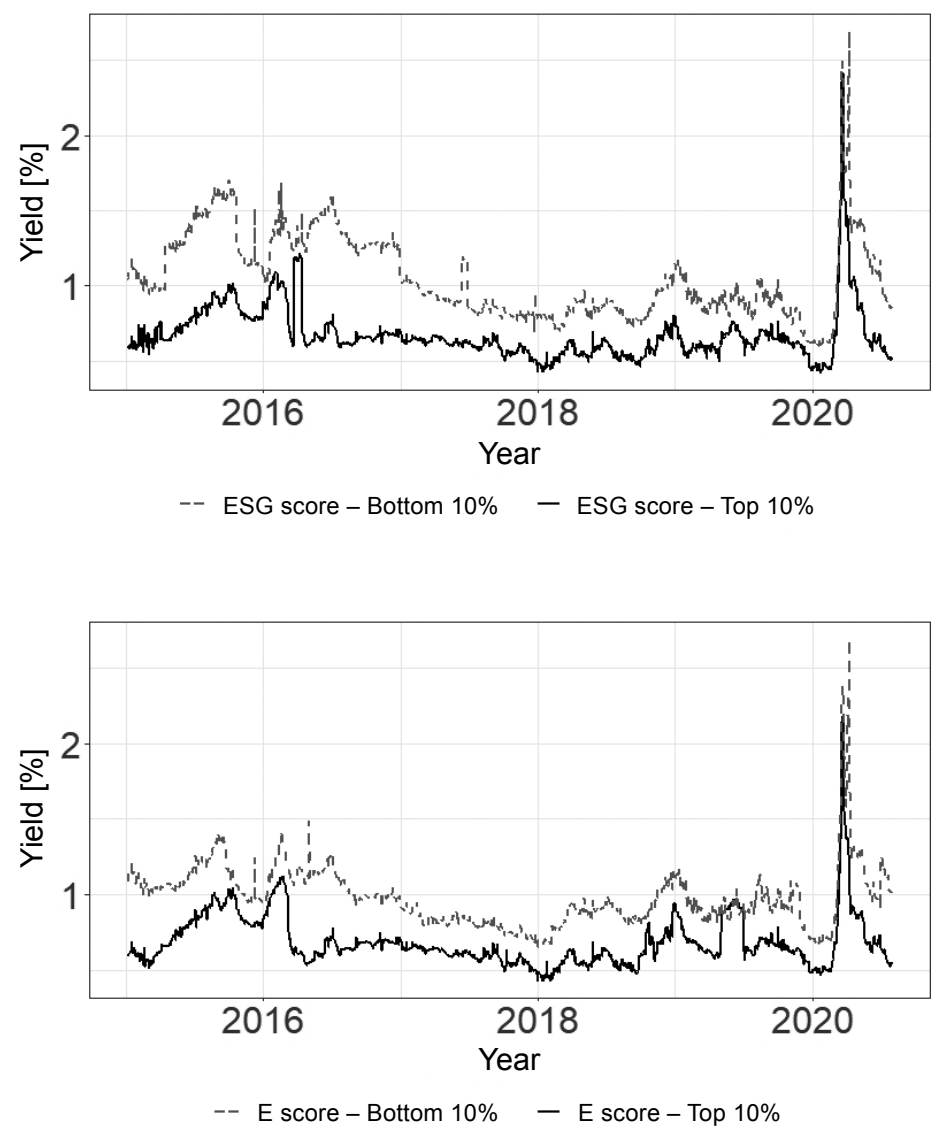


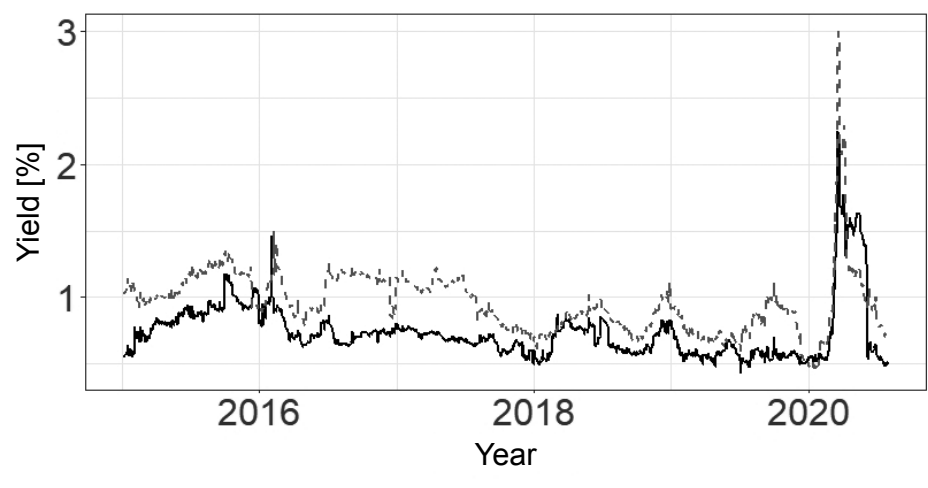

-- S score - Bottom 10\% - S score - Top 10\%

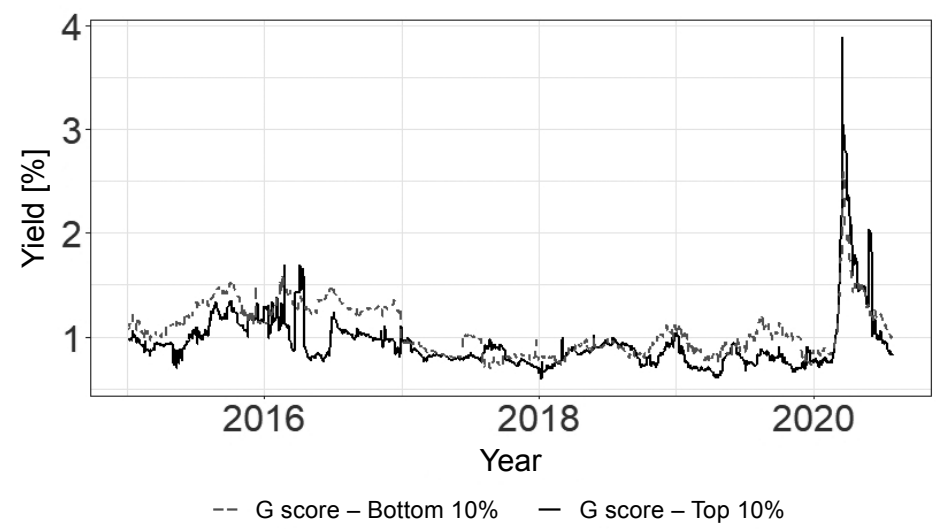

Thanks to the robust nature of the analysis, you can clearly see in Prime 1 that the time series analysis is consistent with the cross-sectional findings received on the last day observed. There is a stable difference of yield spread of corporate bonds categorised by ESG, E, S and G. Just as in the case of daily breakdown, it is clear that the most significant difference measurable by risk premium on the US market is caused by the total ESG score and the environmental (E) score. The difference can be observed in the whole 5-year period, but you should also note the trend appearing when the Corona virus pandemic (COVID-19) exploded. You can find that the difference of yield spread between low and high ESG score companies disappeared. In other words, creditors in a crisis disregard the level of responsible company operations, they deem bonds in the same credit risk category to be equally risky. However, as the panic subsides the trend returns to its pre-pandemic state and yield spreads diverge again. 


\section{Figure 4}

The weighted average of the yield curves of bonds issued by the companies of the Japanese population, the lowest and highest $10 \%$ arranged by their ESG, E, S and G scores from 5 January 2015 to 31 July 2020

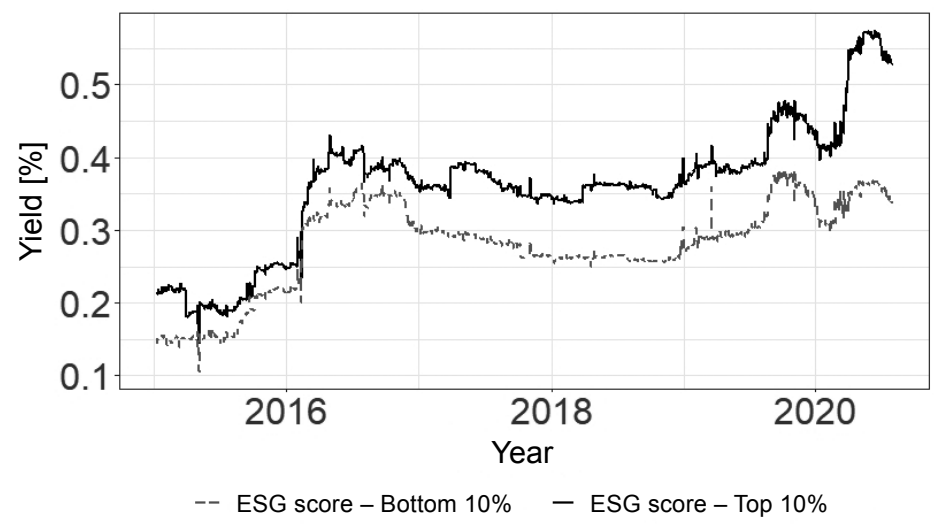

Figure 5

The weighted average of the yield curves of bonds issued by the companies of the European population, the lowest and highest $10 \%$ arranged by their ESG, E, S and G scores from 5 January 2015 to 31 July 2020

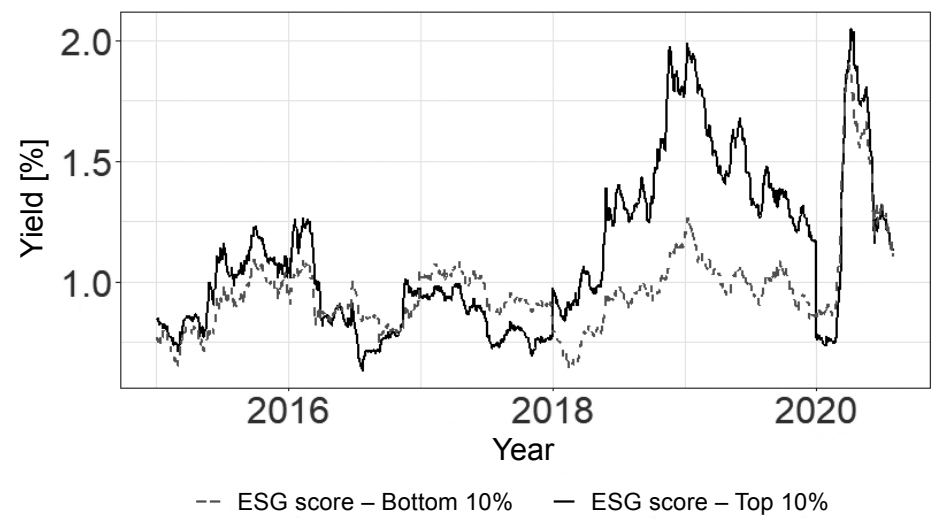

The trends on the European and Japanese bond markets differ both from the US market and each other. While on the Japanese market the yield spread of the bonds issued by the companies with the highest ESG score continues to be higher than those of lower ESG score companies, the trend is changeable on the Euro- 
pean market; added risk is represented by lower or higher ESG rating in different periods. The trends can be observed on both markets for $\mathrm{E}, \mathrm{S}$ and $\mathrm{G}$ factors alike. In line with the findings you can draw the conclusion that the Japanese and Asian markets refrain from rewarding responsible companies as yet, on the contrary, they deem companies to be riskier if they embark on environmental, social or governance projects instead of keeping their eyes on finances and profitability alone.

Trends of yield spread and ESG rating are varied on the European market. In some periods added risk appears in high ESG score while just the opposite happens at other times, creditors deem responsible corporate management less risky. Further research is needed to reveal what events trigger a turning point on the European markets. In the event of a recession, such as the COVID-19 pandemic in 2019, however, the trends appearing are similar to the US market. The importance of non-financial risk mitigation declines, good and bad ESG performers alike are deemed risky.

Our time series findings are consistent with the results of several earlier studies made on stock markets (e.g. Bennani et al., 2018). It was the US stock market where responsible corporate management resulted in added return compared to the benchmark first, which then spilled over to the European markets, while it still has no or very low impact on the Asian markets. On the other hand, the trend appeared delayed on the bond markets; ESG related risk mitigation is already present on the US markets, there is a transition on the European markets but it has not reached the Japanese market, on the contrary, creditors deem it risky.

\section{SUMMARY}

Recalling the findings of the study and thanks to its robust nature, we can draw the conclusion that debtors' risk assessment in the USA is not based on financial considerations alone. The same trend could already be observed on stock markets, however, its presence on bond markets means that ESG-linked risk is getting built into creditors' expectations too. We are talking about the expectations of groups of people (creditors) that are much less exposed to loss incurred in the event of a potential bankruptcy since creditors' claims are satisfied earlier than those of shareholders.

In the USA, the ESG rating is a separating factor of companies within the same credit rating category with the same financial creditworthiness. Over the last five years the market has deemed companies riskier if their ESG scores were lower, i.e. they have displayed less responsible management environmentally, socially or in their governance. The effect did not only appear in the total score (ESG) but also 
in its factors. Another trend appearing is that the better debtor rating a company has the more responsible management matters to its creditors. On the other hand, in poorer credit rating categories it is detrimental for a company if it focuses on responsible operation side by side with solvency. The trend is varied on the European markets but quite opposite on the Asian (Japanese) markets where corporate management is assessed negatively if they also consider non-financial aspects.

The above study raises further quantitative and qualitative questions. For instance, are there events catalysing the changing trend on the European markets, or what is in the background of the trend observed on the Japanese market.

\section{REFERENCES}

Amel-Zadeh, Amir -Serafeim, George (2017): Why and How Investors Use ESG Information: Evidence from a Global Survey. Financial Analysts Journal 74(3), 87-103., DOI: http://dx.doi. org/10.2139/ssrn.2925310.

Anderson, Nicole - SLeAth, John (2001): New estimates of the UK real and nominal yield curves. Bank of England Working Paper Series, https://www.bankofengland.co.uk/-/media/boe/files/ working-paper/2001/new-estimates-of-the-uk-real-and-nominal-yield-curves.pdf?la=en\&hash

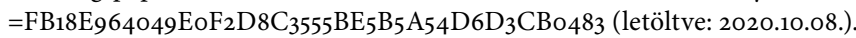

Bennani, Leila - Le Guenedal, Théo - Lepetit, Frederic - Ly, Lai - Mortier, Vincent - RonCalli, Thierry - Sekine, Takaya (2018): How ESG Investing Has Impacted the Asset Pricing in the Equity Market. DOI: http://dx.doi.org/10.2139/ssrn.3316862.

van Duuren, Emiel - Plantinga, Auke -Scholtens, Bert (2016): ESG Integration and the Investment Management Process: Fundamental Investing Reinvented. Journal of Business Ethics 138, 525-533., DOI: https://doi.org/10.1007/s10551-015-2610-8.

FAIN, MÁTÉ (2020): A vállalati társadalmi teljesítmény rövid távú hatásai a pénzügyi jövedelmezőségre [Short-term effects of corporate social performance on financial profitability]. ]Köz-Gazdaság Review of Economic Theory and Policy 15(2), 163-179.

Friede, Gunnar - Busch, Timo- Bassen, Alexander (2015): ESG and financial performance: aggregated evidence from more than 2000 empirical studies. Journal of Sustainable Finance \& Investment 5(4), 210-233., DOI: 10.1080/20430795.2015.1118917.

Gillan, Stuart L. -Starks, Laura T. (2007): The Evolution of Shareholder Activism in the United States. Journal of Corporate Finance 19(1), 55-73. DOI: https://doi.org/10.1111/j.17456622.2007.00125.X.

Hoepner, Andreas - Oikonomou, Ioannis - Sautner, Zacharias - Starks, Laura T. - Zhou, XIAOVAN (2019): ESG Shareholder Engagement and Downside Risk. European Corporate Governance Institute - Finance Working Paper No. 671/2020. DOI: http://dx.doi.org/10.2139/ ssrn.2874252.

MSCI (2020): ESG 101: What is ESG? (https://www.msci.com/what-is-esg, letöltve: 2020.10.08.).

MSCI (2020): ESG Ratings (https://www.msci.com/esg-ratings, letöltve: 2020.10.08.).

Naffa Helena - Dudás FanNi (2020): Milyen szerepet töltenek be az országszintủ ESG-indikátorok, valamint a globális pénzügyi inklúziós indikátorok a szociális és pénzügyi jólét meghatározásában? [The role of country-level ESG indicators and global financial inclusion indicators in assessing social and financial welfare]. Köz-Gazdaság - Review of Economic Theory and Policy 15(2), 156-162. 
Orlitzky, Marc - Schmidt, Frank L. - Rynes, SARA L. (2003): Corporate Social and Financial Performance: A Meta-Analysis. Organizational Studies 24(3), 403-441. DOI: https://doi.org/10. 1177/0170840603024003910.

Refinitiv (2020): Environmental, Social, Governance (ESG) Scores from Refinitiv. (https://www.refinitiv.com/content/dam/marketing/en_us/documents/methodology/esg-scores-methodology. pdf, letöltve: 2020.10.08.)

Reuters (2017): Thomson Reuters Credit Curve Methodology. (https://www.aer.gov.au/system/files/ ACCC\%20-\%20Thomson\%2oreuters\%2ocredit\%2ocurve\%2omethodology\%20-\%2oNote\%20 for\%2othe\%2oAER\%2O-\%20April\%202017_1.pdf letöltve: 2020.10.08.)

Shrivastava, Paul - Zsolnai, Laszlo - Wasieleski, David -Stafford-Smith, Mark -Walker, Thomas -Weber, Olaf -Krosinsky, Cary - Oram, David (2019): Finance and Management for the Anthropocene. Organization \& Environment 32(1), 26-40. DOI: https://doi. org/10.1177/1086026619831451.

US SIF (2016): Report on US Sustainable, Responsible and Impact Investing Trends 2016 (https://bit. ly/2HriyFp, letöltve: 2020.10 .08 ..

Waggoner, Daniel F. (1998): Spline Methods for Extracting Interest Rate Curves from Coupon Bond Prices. Federal Reserve Bank of Atlanta Working Paper 97-10. DOI: http://dx.doi. org/10.2139/ssrn.86789. 